\title{
Global Professional Service Firms and institutionalization
}

James Faulconbridge, Lancaster University, UK (j.faulconbridge@lancaster.ac.uk)

Daniel Muzio, Newcastle University, UK (Daniel.muzio@newcastle.ac.uk)

Please cite as: Faulconbridge, JR. Muzio, D. (2017) Global professional service firms and institutionalization. In Seabrooke, L. Henriksen, LF (Eds) Professional networks in transnational governance. Cambridge University Press, Cambridge, 219-232.

\section{Introduction}

The global professional service firm (GPSF) is now a significant agent in national and transnational political economies. Yet, in existing literatures on transnational governance the role of these firms is somewhat hidden by a tendency to place the professions at centre stage. Thus, whilst the literature recognizes how 'the professions in modern society have assumed leading roles in the creation and tending of institution' (Scott, 2008:219), there has been less systematic attention to the role of GPSFs as institutional agents. In part this can be explained by the fact that the sociology of the professions traditionally does not recognize the analytically distinct nature or role of professional organizations within professionalization and broader institutionalization projects (Faulconbridge and Muzio, 2012). Yet, such a state of affairs no longer seems tenable. GPSFs have their own agendas, capabilities and patterns of activities that are both related to but also distinct from those of the wider professional communities to which they belong. From prominent and politically inscribed cases such as the General Agreement on Trade in Services (GATS) (Arnold, 2005) and carbon trading markets (Knox-Hayes, 2009), to less-well reported and softer systems such as regimes around 
sustainable building design (Bulkeley and Jordan, 2012; Faulconbridge, 2013) and competition (antitrust) agreements (Morgan, 2006), GPSFs have been central actors in the production of new forms of governance. Such compacts are of course important for those actors directly engaged in the issues in question. Perhaps more importantly, though, they also matter because, as Suddaby and Viale (2011) argue, through their actions GPSFs have wider spin-off effects on adjacent fields, whether that is the development of employment law as a result of trade agreements or property financing as a result of sustainable design regimes.

In this chapter we, thus, seek to highlight the importance of advancing the work that does exist on GPSFs in the institutionalization of transnational governance regimes through a more careful consideration of the identities, projects and effects of the firms in question. We contend that in their attempts to develop new markets, services and more efficient internal organizational models, GPSFs exercise far reaching institutional effects as they challenge governance regimes, disrupt/create jurisdictions, and transform identities, practices and systems of regulation in the professions themselves. They do this, we suggest, through three strategies associated with scope of control, defining scales of knowledge resources, and the production of ecologies of linked interests. This chapter provides, then, a contribution to on-going attempts to 'revisit theories of professionalism, which did not fully anticipate the shift of professional work to the context of large organizations' (Suddaby et al., 2007: 25).

\section{The GPSF in context}

It is important to begin by clarifying what exactly is meant by GPSF. Such clarification is Important because we use the term GPSF to refer to two related but subtly different groups of organizations (on this differentiation and the debate it inspires see von Nordenflycht, 2010). On the one hand we have the 'old' professional service firms, old being used to indicate organizations employing 
professionals from long-ago established and state recognised professions. Key examples are accountancy, architecture and law (for analysis of each see respectively Cooper and Robson, 2006; Faulconbridge, 2010; Muzio and Faulconbridge, 2013). Whilst firms have existed in these professions for decades or centuries, they have acquired an increasingly global scale in the latter years of the $20^{\text {th }}$ century. In all cases these 'old' GPSFs exploit the monopolies over markets afforded to them by professional closure regimes which restrict the production and deliver of services to registered individuals and firms structured in line with clearly defined (usually by national professional associations) regulations (Faulconbridge and Muzio, 2007).

One the other hand we have the 'new' professional service firms. 'New' is used to indicate the rise of a series of occupations that have sought to mimic and claim the same status as the 'old' professions whilst developing new organizational forms and practices. Examples include executive search, management consultancy and project management (see respectively Faulconbridge et al., 2008; McKenna, 2006; Hodgson, 2007; Paton et al., 2013). Distinctive about these firms is the absence of a clearly defined status for the 'professionals' employed (they are not part of a state regulated profession), yet a tendency to present services as professional. Such attempts stress knowledge richness, ethical practice and fiduciary role mimicking the logics underlying the state supported closure projects of the 'old' professions (Muzio et al., 2011).

Whilst there are important differences between the 'old' and 'new' professional service firms (as summarised by von Nordenflycht, 2010), we badge both as GPSFs as the two do share one important commonality: the last years of the twentieth and early years of the twenty-first century have seen firms exert significant forms of agency designed to ensure control and influence over key issues such as corporate globalization, trade regulation, carbon markets etc. This agency, which we examine in more detail in the next section of the chapter, emerges from important changes in the strategies of GPSFs over time. 
Organizational strategies and the institutional agency of GPSFs

Figure 1 gives examples of both 'old' and 'new' GPSFs and their key organizational characteristics. GPSFs have not always been so large and influential. In their earliest guise, which for some such as accountancy firms dates back to the late nineteenth century, GPSFs simply followed their clients. Overseas offices were established in locations where home-country clients had or were considering setting up operations (Beaverstock et al., 1999; Cooper and Robson, 2006; Bagchi-Sen and Sen, 1997; Faulconbridge et al., 2008). Globalization was, then, very much about providing a service to existing clients, and thus sometimes involved establishing offices but, in cases where client needs were sporadic, could also mean establishing best friend alliances with local companies.

[Insert Figure 1 somewhere here]

Over time, the strategies of GPSFs have evolved. Initial forays overseas gave organizations a taste for new markets and highlighted the potential to acquire new clients. Hence, GPSFs became market seekers, particularly in the 1980s and 1990s as neoliberal reforms led to more and more clients globalizing their operations. This created an ever greater role for fully owned overseas offices (on this development trajectory see Bagchi-Sen and Sen, 1997; Faulconbridge et al., 2008). In terms of our discussion here, the initial two stages (client follower and market seeker) are, however, of less significance than a third stage, which we call market making. In this stage, which is associated with the last years of the twentieth and first decade of the twenty-first century, GPSFs became active agents in the institutionalization of new transnational regimes. This involves both the importing of already existing products and markets into new geographical contexts as part of efforts to reduce the complexities of transnational practice - exemplified by the cases of bankruptcy law (Halliday and Carruthers, 2009) and sustainable building assessment tools (Cole and Valdebenito, in press) - and the creation of supra-national compacts designed to govern activities outside of the nation-state - 
as exemplified by GATS (Arnold, 2005) and competition agreements (Morgan, 2006). In the market making stage, GPSFs rely upon their owned offices to act as staging posts for forms of institutional work designed to shape rules, norms and logics in ways that locate GPSFs at the centre of new economic, political and social regimes (see Beaverstock et al., 2010; Smets et al., 2012; Suddaby et al., 2007). It is to the nature of this institutional work and its impacts we now turn.

\section{GPSFs and their institutional work strategies}

This section examines key trends in relation to how GPSFs exercise institutional agency. This is in line with the recent focus in the sociology of the professions (Leicht and Fennell, 2008; Scott, 2008; Viale and Suddaby, 2011; Muzio et al, 2013) on the agency of the professionals as 'the preeminent institutional agents of our time' (Scott, 2008, 219), who as 'lords of the dance' choreograph the broader transformation of societal and economic systems.

In this analysis, we adopt the concept of institutional work, introduced by Lawrence et al. (2009), to capture the diverse forms of GPSF action that have led to new transnational settlements relating to issues as diverse as climate change, international trade and the governance of the global economy. By institutions we mean the widely recognised rules, norms and cultural-cognitive schemes that govern everyday practice relating to particular issues (on this see Scott, 2008); thus institutions are the key structuring device of economies and societies. These institutional regimes are increasingly transnational in scale, in contrast to earlier periods in which national scale regimes dominated (Djelic and Quack, 2010). The concept of institutional work understands the process of institutionalization by which (transnational) rules, norms and cultures come to gain widespread recognition and influence to involve three forms of agency: creation, maintenance and/or disruption. We suggest disruption and creation are especially relevant to our story of the role of GPSFS in the development of transnational governance regimes, with agency being exercised to 
disrupt or create institutions depending on what is needed to protect the interests of the GPSFs in question.

In terms of the actual forms that agency takes, the institutional work literature draws our attention to the importance of a diverse array of strategies, from the overt such as lobbying (Greenwood et al., 2002) and the deployment of discourses to legitimise and inspire change (Phillips and Nelson, 2004), to the more covert, banal and often missed such as the use of human resource practices, like recruitment and training, to produce suitable individuals which internalize appropriate values and norms (Faulconbridge et al., 2012; Pache and Santos, 2010), and the quiet role modelling of new institutional regimes which then organically diffuse and gain widespread influence (Smets et al., 2012). We suggest that all of these forms of agency are relevant to GPSFs and their attempts to develop transnational governance regimes.

As an illustrative case study, drawing on series of published studies (Arnold, 2005; Robson et al., 2007; Suddaby et al, 2007), we use the example of Big Four accountancy firms. These have been selected because they are not only the most sophisticated GPSFs but are, as indicated by Figure 1, amongst the largest and most global GPSFs. Furthermore, and crucially for our arguments here, they have been particularly significant within processes of institutionalization, interacting with nation states and supra-national entities like the EU, WTO and IMF to reframe key institutions in ways that support their own professional projects. Crucially these attempts at institutional work have had broader repercussions, as they reverberate through the transnational field affecting existing institutions such as local regulation and qualification systems, national markets and occupational jurisdictions, and established societal and corporate practices. In particular, we focus below on three interrelated examples: the role of the Big Four accountancy GPSFs in reframing established auditing practices and markets (Robson et al., 2007); their attempts to change accountancy qualification regimes to create a new transnational designation for business professionals (Suddaby et al, 2007); 
and their use of WTO procedures to challenge national regulations as part of efforts to develop and control a global market for their services (Arnold, 2005).

\section{Three examples of institutionalization by GPSFs}

Our first example of the institutional role played by Big Four accountancy firms refers to an issue which is at the heart of the accountancy professionalization project (MacDonald, 1995): the redefinition of auditing. Auditing has traditionally represented one of the economic cornerstones of the accountancy profession. Furthermore, as a highly visible example of what accountants do, it is one of their key sources of (self) identity, as well as one of the most persuasive justifications for their professional status as gatekeepers (Coffee, 2005) of public interest (the protection of investors, creditors and the general public through the certification of corporate accounts). Yet, despite its foundational role at the heart of the accountancy project, auditing fees have over the last few decades been under growing pressure. This reflects the increasing commodification and routinization of this area of practice as well as the reluctance of clients to pay for a regulatory service which does not directly add value to their business (Coffee, 2005). In this context, accountancy firms have been growing alternative and more profitable lines of business such as tax advisory and management consultancy services, with auditing divisions decreasing in economic and political significance within the firms which they historically dominated. Indeed, reflecting this development, during the 1990s the main strategy of the Big Four centred around the treatment of auditing as a loss leader to secure clients for more lucrative consultancy services, with auditing partners being rewarded for their ability to cross-sell the firms' broader expertise to their clients (Coffee, 2005; Robson et al., 2007).

Consequently, firms embarked on a project to redefine and reframe auditing practices through the development of Business Risk Audit (BRA) methodologies (Robson et al., 2007). BRA 
expands the remit of the traditional audit to include a comprehensive focus on risk management and business assurance. In particular, audits are broadened to include the analysis of corporate strategies and business processes and the way these generate business risks which in turn affect financial statements. This repositioning of the audit was theorized by firms as important for clients not only because as a more holistic perspective it was more likely to increase the accuracy and reliability of audits, but also because by enlarging its remit BRA methodologies redefine auditing from a 'compliance' to a 'value-creation' tool. By casting a wider perspective on the operations and activities of a firm, BRA generates valuable knowledge on its current performance, as well as future risks and opportunities. Thus, through the development of BRA large accountancy firms have effectively redrawn the boundaries between auditing, risk management and management consultancy; as a result auditors are empowered to advice clients on a wide range of matters pertaining to their business whilst the economic potential of auditing services is maximised.

Our second example broadens our focus from the technical (i.e. auditing) to the regulatory. Historically, professions have developed within the confines of the nation state and professionalization processes have often unfolded as part of broader state building projects (Burrage and Torstendahl, 1990). In this context, national regulations tend to control both who can deliver professional services (control over the production of producers) and how professional activities can be legally organized, produced, traded and consumed (control over the production by producers) (Abel, 1988). This implies that whilst global professional services firms have invested to develop one firm models of management (Muzio and Faulconbridge, 2013) based on globally integrated structures and seamless service delivery practices, their operations are often disrupted and fragmented by national regulatory requirements (Faulconbridge, 2008). Big Four accountancy firms have responded to such national impediments by actively trying to subvert local restrictions to their activities, developing in the process a global market for their services as well as helping to consolidate emerging transnational governance regimes which coexist with national regimes. 
At the heart of the Big Four's attempts to change national regulations are WTO initiatives such as GATS article VI:4 and the Disciplines on Domestic Regulation in the Accountancy Sector; these being successfully used to challenge domestic regulations which restricted global accountancy firms' activities in specific jurisdictions. Thus the autonomy of democratically elected institutions, such as national governments and professional associations, over traditionally domestic matter such as credentials, qualification regimes, ethical codes and standards of practice became subordinated to WTO mandated tests of necessity and proportionality, as well as to analyses of their compatibility with international standards. The inability of Greece in the 1990s to resist liberalization and to reregulate its own domestic accountancy profession, in face of opposition from large professional services firms and international organizations such as the OECD, represents a clear example of the effects of these measures (Caramanis, 2002).

Our final example extends this analysis and indicates how large firms have been actively seeking to build a transnational training and qualification system around the new XYZ designation (Suddaby et al., 2007; Covaleski et al., 2003). This was intended as a transnational multidisciplinary qualification for global business professional; an elite MBA for accountants which crucially sought to deliver international consistency, visibility and recognition in professional qualification regimes so as to support more effectively the requirements of GPSFs and their clients. XYZ effectively operated as a market driven qualification whose legitimacy rested on its ability to add value to its holders, employers and users. The qualification effectively sanctioned a division between a business advisory elite which operated at a transnational level and the rest of the accountancy profession which continued to be embedded and constrained by national institutions, values and arrangements (Suddaby et al., 2007). Although ultimately unsuccessful, the XYZ project provides a clear example of a transnational professional qualification which was explicitly designed to support the requirements and activities of GPSFs. In doing so it would have provided Big Four accountancy firms with an effective way to short-circuit national systems for the regulation of the production of producers and to recruit individual practitioners educated and socialized into the realities and norms of 
transnational professional work. This points out to the increasing role of GPSFs as sites of professional identity formation and regulation (Cooper and Robson, 2006) as firms deploy increasingly sophisticated HRM techniques, such as recruitment and selection, mentoring and corporate training programmes to mould the subjectivities of the professionals they employ in ways that best serve corporate priorities (Covaleski et al., 1995; Anderson Gough et al., 1998; Grey, 1998). As such, this example indicates how 'the historical regulatory bargain between professional associations and nation states is being superseded by a new compact between conglomerate professional firms and transnational trade organizations' (Suddaby et al., 2007: 334). In this context, GPSFs are hollowing out historical functions of the nation state and reframing these as part of new transnational governance regimes of which they are a key component.

\section{GPSFs in transnational governance ecologies}

The three examples from the accountancy profession discussed above all point to significant forms of institutional change driven by GPSFs as they disrupt established institutions and create new ones to support their organizational strategies and activities. Thus the traditional audit is transformed to cater for a broader range of business assurance functions and, in the process, helps to develop new lines of business. National regulatory systems are challenged and overhauled as part of attempts to legitimise the strategies and activities of GPSFs and to produce a global market for their services. Finally, new professional qualification systems and credentials are sought to support the needs of global practice, threatening to fragment established professional projects and institutionalizing divides between global professional elites and local practitioners.

One important thing to notice here is how the professionalization projects pursued by GPSFs trigger broader processes of institutionalization. For instance, it was the attempts by accountancy firms to circumvent the effects of the restrictions imposed by Sabannes Oxley (2002) and by auditing 
departments to raise their profitability and prestige within their firms that led to the transformation of auditing practices. Similarly, attempts by large accountancy firms to use WTO regulations to expand their markets contributed to the hollowing out of the role of the nation-state and the consolidation of transnational governance regimes around the professions themselves. And, importantly, GPSFS were not isolated actors in the institutional transformations previously described. Rather, they acted as part of dense coalitions formed with key stakeholder in their broader field of practice. Thus, accountancy firms worked closely with academia to develop, diffuse and legitimize BRA, by funding research and teaching posts, providing case studies and other materials, co-authoring key texts (such as Bell et al., 1997 - which acts as the unofficial bible for BRA), and sponsoring as well as participating in relevant academic conferences (such as KPMG's Business Measurement Process Conference). Through these activities large firms have been able to shape the academic agenda and leverage this to help promote BRA methodologies; this being possible because of the desire of universities to reform their relationship with industry and their role in professional governance regimes.

At the same time, because BRA calls on a broad range of business skills and knowledge in areas such a strategy, operations and risk management, which go beyond traditional auditing curricula and qualifications, accountancy firms have developed close working relations with the professional associations who set and police standards, frameworks and regulations in the accountancy field. In particular, the delivery of BRA required the development of new curricula, qualification pathways and professional credentials. Professional bodies, keen to reproduce their role and importance in a changing political economy, had a clear incentive to cooperate with Big Four firms to affect institutional change. For instance, the Institute of Chartered Accountants of England and Wales (ICAEW) in its 1998 Green paper 'Creating the Added Value Business Advisor' promoted the development of new qualification pathways which explicitly targeted the development of the generalist business and management skills. Indeed, by the start of the new millennium, $25 \%$ of the ICAEW training syllabus was concerned with business risk and assurance 
(William, 2001 cited in Robson et al 2007). Importantly, such networks involve international organizations such as the International Auditing and Assurance Standards Board (IAASB) of the International Federation of Accountants, who, as part of its Audit Risk Project, revised international auditing standards to reflect and in turn endorse the new BRA agenda in auditing practice. In particular, these revisions, in line with BRA methodology, led to the mainstreaming of risk assessment standards, which had traditionally been separate and peripheral issues, as core concerns within regulations on financial statement audits (IAASB 2002; 2003). Similarly, Big Four accountancy firms joined forces with international trade lobbies such as International Financial Services London (IFSL) and the US Coalition of Services Industries (USCSI), transnational professional networks such as the International Federation of Accountants (IFAC), multinational clients such as UBS, BT and DHL, and international organizations such as the WTO, the OECD and the EU Commission to drive their deregulatory projects (Arnold, 2005).

The intimate relationships between the institutional work of the Big Four and the allied projects of universities and regulators is supported by revolving door style arrangements through which Big Four firms funded named accountancy chairs at leading universities (such as Ira Thomson's KPMG Professorship in Accountancy at the University of Illinois) and key staff moved between Big Four accountancy firms to key positions in professional associations and international regulatory bodies, and vice-a-versa.

The impacts of such links is to place GPSFs such as the Big Four accountancy firms in de- and re-regulatory compacts with groups who share a similar institutional agenda including industry and lobby groups (such as the Liberalization of Trade in Services Committee), neoliberal states (such as the US and the UK) and transnational institutions (such as the WTO) which actively seek to expedite and extend measures associated with the construction of new transnational governance regimes. As such, the institutional agency of GPSFs cannot be disconnected from wider forms of transnational political economic settlement and complexly linked ecologies. GPSFs are, then, important 
stakeholders in the Washington Consensus and subscribe to its neoliberal vision of unfettered competition and open markets (crucially including professional services). This is perhaps unsurprising; after all, economic interest certainly ties GPSFs into a symbiotic relationship with the masterminds of the neoliberal agenda, as the new economic order delivers to them significant financial gains and opportunities whilst their services and expertise is essential to the smooth operation of transnational capitalism.

\section{The process and impacts of institutional work by GPSFs}

Reflecting the suggestion in the chapter by Seabrooke and Henriksen (this volume) that issues of scope, autonomy, resources, hiring, and knowledge are significant in analyses of the role of professionals in transnational regimes, the discussion here reveals three important dynamics in the transnational institutional work of GPSFs.

Theorizing the scope of control. Exemplified by work associated with the institutionalization of BRA, we see GPSFs engaging in concerted efforts to expand the scope of their control over certain markets through a theorization process similar to that outlined by (Greenwood et al., 2002). This process identifies the problem at hand, and the solution GPSFs can provide to this problem. In the case of BRA the problem related to the reactive nature and the limited value-added of traditional auditing services, and the solution was provided by the integrated audit and risk assurance methodologies developed by Big Four firms. Through this theorizing firms were able to position themselves in a central position within the increasingly transnational field of business advisory services (Arnold, 2005; Barrett et al., 2005; Suddaby et al., 2007). Similar processes of theorization are present in other cases relating to the role of GPSFs in the development of transnational regimes

- such as international bankruptcy and sustainable building design - yet to date the existing 
literature pays limited attention to the firms in question, something this chapter and the theoretical framing here developed can help to resolve.

Defining scales of knowledge resources. As part of efforts to secure influence in transnational markets and regimes, GPSFs engage in sustained efforts to detach their claims of knowledge and expertise from national jurisdictions and reattach them to transnational regimes. This is associated with broader evolutions in the basis of the knowledge claims of the professions (Evetts, 1998, 2011), particularly towards a transnational arena in which the state is just but one actor in governance regimes (Faulconbridge and Muzio, 2012). In the case of accountancy, this process is exemplified by the exploitation of the GATS regime to redraw national jurisdictions and challenge local regulations. This redefining of scales of knowledge in part means maintaining existing logics of professional practice - for instance the fiduciary logic associated with accountancy (Malsch and Gendron, 2013) - and exploiting the associated knowledge in claims about the centrality of the profession in transnational regimes.

Transnational knowledges are, then, crucial resources for legitimacy claims. This often means invoking a process of rescaling onto the transnational level of the knowledges that professions have traditionally deployed at the national level to accomplish their professionalization projects. This process is further exemplified by the attempted XYZ qualification in accountancy; this new resource being designed to operate and be policed by transnational professional associations. Other examples of such resources include the protocols, deontological codes and principles of best (ethical) practice set out and monitored by transnational professional associations and networks such as the International Bar Association, International Union of Architects, the International Auditing and Assurance Standards Board and the International Competition Network (on such bodies see Faulconbridge and Muzio, 2012; Hussain and Ventresca, 2010).

Forming and exploiting ecologies of shared interest. A key aspect of the institutional work performed by GPSFs is the strategic effort to collaborate with and piggy-back on the agendas of 
other stakeholders in emerging transnational regimes. In the case of accountancy (as well as other GPSFs), such an ecology of shared interest is exemplified by relationships with international organizations like the WTO, the World Bank and IMF, as well as neo-liberal nation-states (such as the UK and US) and academic institutions. It is important to note that this is not an ecology that solely benefits the GPSF. At the same time they also serve the agendas of the collaborating organizations, with a mutual dependency developing. For instance, international organizations require the expertise of professional organizations to manage globalization processes and coordinate transnational governance regimes. Any illusions of professionals being separated from and impervious to commercial interest are, then, shattered in these emerging transnational ecologies where shared interest bind the GPSF to the neoliberal agenda of the Washington consensus (Morgan, 2006). This suggests that transnational regimes are the outcome of a strategic compact between parties that together seek to control issues that are central to the wider economic and social order.

\section{Conclusions}

We have in GPSFs a crucial locus of power and agency that is integral to and also exemplary of the construction of new transnational regimes that are transforming the system of the professions (Abbott, 1988) as well as the wider political-economy. Reflecting broader trajectories, GPSFs in various ways disconnect themselves from national professional projects and redefine their jurisdictions through three processes outlined in the previous section of the chapter. It thus seems crucial to more carefully locate GPSFs in debates about transnational governance and institutional change, transcending the established tendency to focus on professional firms and individual professionals in isolation, without consideration of the broader institutional context they inhabit and that help form. 
In closing we propose three agendas for future research that would enhance understanding of the role of GPSFs in transnational regimes. First, it seems important to further unpack the organizational strategies of the firms in question. By this we mean the ways that individual GPSFs seek to enact the scope, knowledge resource and ecology strategies outlined in this chapter. To date we know little about the efforts made by individual firms as part of their corporate strategies to enact transnational institutional projects. Second, the heterogeneity in the successes of GPSFs and the regimes they sanction in different countries needs closer scrutiny. As Djelic and Quack (2003) highlight, transnational regimes are additional layers of governance that coexist with national regimes. Yet, little effort has been made to bring back-in the national scale and consider how transnational compacts 'come down to the ground' and get operationalized in and through individual nation-states, with implications for the role of GPSFs within different jurisdictions and political-economic systems. The development of the international bankruptcy regime exemplifies this (Halliday and Carruthers, 2009), as it involved negotiations and compromises in each county deployed in. It would thus seem useful to provide more comparative work focussed on the efforts and outcomes of the activities of GPSFs in different national contexts. Third, better specifying the ecologies of shared interest that GPSFs are part of would be helpful in better revealing the new kinds of compacts and networks associated with transnational governance. For instance, we know little about the way GPSFs in the same sector (e.g. law) come together to form alliances, how GPSFs from different sectors compete or collaborate, or about how GPSFs manage to insert themselves into the agendas of the WTO and other supra-national organisations.

There is, then, much to be done to further specify the role of GPSFs in transnational institutional processes including the creation and operation of those regimes that are so central to the functioning of contemporary economies and societies.

\section{References}


Abbott, A. 1988: The system of professions: an essay on the division of expert Labour. Chicago: University of Chicago Press.

Anderson-Gough, F., Grey, C. and Robson, K. 1998: Making up accountants: the professional and organizational socialization of trainee chartered accountants. Aldershot: Ashgate/ICAEW.

Arnold, P. 2005: Disciplining domestic regulation: The World Trade Organization and the market for professional services. Accounting, Organizations and Society 30, 299-330.

Bagchi-Sen, S. and Sen, J. 1997: The current state of knowledge in international business in producer services. Environment and Planning A 29, 1153-1174.

Barrett, M., Cooper, D.J. and Jamal, K. 2005: Globalization and the coordinating of work in multinational audits. Accounting, Organizations and Society 30, 1-24.

Beaverstock, J.V., Faulconbridge, J.R. and Hall, S.J.E. 2010: Professionalization, legitimization and the creation of executive search markets in Europe. Journal of Economic Geography 10, 825-843.

Beaverstock, J.V., Smith, R. and Taylor, P.J. 1999: The long arm of the law: London $\ngtr$ s law firms in a globalising world economy. . Environment and Planning A 13, 1857-1876.

Bell, T. B., Marrs, F. O., Solomon, I., \& Thomas, I. 1997: Auditing organizations through a strategic systems lens. Montvale, NJ: KPMG LLP.

Bulkeley, H. and Jordan, A. 2012: Transnational environmental governance: new findings and emerging research agendas. Environment and Planning C: Government and Policy 30, 556-570.

Burrage, M., Jarausch, K. and Sigrist, H. 1990: An actor-based framework for the study of the professions. In Burrage, M. and Torstendahl, R., editors, Professions in theory and history, London: Sage, 203-225.

Caramanis, C. 2002:. The interplay between professional groups, the state and supranational agents: Pax Americana in the age of 'globalisation'. Accounting, Organizations and Society, 27(4/5), 379408.

Coffee, J.C. 2006: Gatekeepers: Professions and corporate governance. New York: Oxford University Press. 
Cole, R.J. and Valdebenito, M.J. in press: The importation of building environmental certification systems: international usages of BREEAM and LEED. Building Research \& Information Available online early at http://www.tandfonline.com/doi/abs/10.1080/09613218.2013.802115\#.UePIMaxdDR8

Cooper, D.J. and Robson, K. 2006: Accounting, professions and regulation: Locating the sites of professionalization. Accounting, Organizations and Society 31, 415-444.

Covaleski, M. A., Dirsmith, M. W., Heian, J. B., \& Samuel, S. 1998: The calculated and the avowed: techniques of discipline and struggles over identity in Big Six public accounting. Administrative Science Quarterly, 43, 293-327.

Covaleski, M. A., Dirsmith, M. W., \& Rittenberg, L. 2003:. Jurisdictional disputes over professional work: the institutionalization of the global knowledge expert. Accounting Organizations and Society, 28, 323-355.

Djelic, M.L. and Quack, S. 2003: Theoretical building blocks for a research agenda linking globalization and institutions. In Djelic, M.L. and Quack, S., editors, Globalization and institutions: Redefining the rules of the economic game, Cheltenham: Edward Elgar.

Djelic, M.L. and Quack, S. 2010: Transnational communities and governance. In Djelic, M.L. and Quack, S., editors, Transnational communities. Shaping economic governance, Cambridge: Cambridge University Press, 3-36.

Evetts, J. 1998: Professionalism beyond the nation-state: international systems of professional regulation in Europe. International Journal of Sociology and Social Policy 18, 47-64.

Evetts, J. 2011: A new professionalism? Challenges and opportunities. Current Sociology 59, 406-422. Faulconbridge, J. and Muzio, D. 2012: The rescaling of the professions: towards a transnational sociology of the professions. International Sociology 27, 109-125.

Faulconbridge, J.R. 2010: Global architects: learning and innovation through communities and constellations of practice. Environment and Planning A 42, 2842-2858. 
Faulconbridge, J.R. 2013: Mobile 'green'design knowledge: institutions, bricolage and the relational production of embedded sustainable building designs. Transactions of the Institute of British Geographers 38, 339-353.

Faulconbridge, J.R., Hall, S. and Beaverstock, J.V. 2008: New insights into the internationalization of producer services: Organizational strategies and spatial economies for global headhunting firms. Environment and Planning A 40, 210-234.

Faulconbridge, J.R. and Muzio, D. 2007: Reinserting the professional into the study of professional service firms: the case of law. Global Networks 7, 249-270.

Faulconbridge, J.R., Muzio, D. and Cook, A. 2012: Institutional legacies in TNCs and their management through training academies: the case of transnational law firms in Italy Global Networks 12, 48-70.

Greenwood, R., Suddaby, R. and Hinings, C.R. 2002: Theorizing change: The role of professional associations in the transformation of institutionalized fields. The Academy of management journal $45,58-80$.

Grey, C. 1998: On being a professional in a" Big Six" firm. Accounting, Organizations and Society 23, 569-587.

Halliday, T.C. and Carruthers, B.G. 2009: Bankrupt: global lawmaking and systemic financial crisis. Stanford: Stanford Univ Press.

Hodgson, D. 2007: The New Professionals; Professionalisation and the Struggle for Occupational Control in the Field of Project Management' In Muzio, D., Ackroyd, S. and Chanlat, J.F., editors, Redirections in the Study of Expert Labour: Medicine, Law and Management Consultancy, Basingstoke: Palgrave.

Hussain, A.A. and Ventresca, M.J. 2010: Formal organizing and transnational communities: evidencefrom globalfinance governance associations, 1879-2006. In Djelic, M.L. and Quack, S., editors, Transnational Communities: Shaping Global Economic Governance, Cambridge: Cambridge University Press, 153-173. 
International Auditing and Assurance Standards Board (IAASB) 2002: Audit risk: proposed international standards on auditing and proposed amendment to ISA 200. Objective and principles governing an audit of Financial statements. Request for Comments and Explanatory Memorandum to Exposure Drafts. New York: IAASB.

International Auditing and Assurance Standards Board (IAASB) 2003: International standard on auditing 200. Objective and principles governing an audit of Financial statements New York: IAASB.

Lawrence, T. B., Suddaby, R. and Leca, B. Eds. 2009:. Actors and Agency in Institutional Studies of Organizations. Cambridge: Cambridge University Press.

MacDonald, K.M. 1995: The sociology of the professions. London: Sage.

McKenna, C.D. 2006: The world's newest profession. Management consulting in the twentieth century. Cambridge: Cambridge University Press.

Morgan, G. 2006: Transnational actors, transnational institutions, transnational spaces: the role of law firms in the internationalization of competition regulation. In Djelic, M.-L. and SahlinAndersson, K., editors, Transnational governance. Institutional dynamics of regulation, Cambridge: Cambridge University Press, 139-160.

Muzio, D. and Faulconbridge, J.R. 2013: The global professional service firm: 'one firm' models versus (Italian) distant institutionalised practices Organization Studies 34, 897-925.

Muzio, D., Hodgson, D., Faulconbridge, J., Beaverstock, J. and Hall, S. 2011: Towards corporate professionalization: The case of project management, management consultancy and executive search. Current Sociology 59, 443-464.

Pache, A.-C. and Santos, F. 2010: When worlds collide: The internal dynamics of organizational responses to conflicting institutional demands. Academy of management Review 35, 455-476. 
Paton, S., Hodgson, D. and Muzio, D. 2013: 'The price of corporate professionalisation: analysing the corporate capture of professions in the UK and consequences for expert labour. New Technology Work and Employment, 28:3, 227-240

Phillips, N., Lawrence, T.B. and Hardy, C. 2004: Discourse and institutions. Academy of management Review 29, 635-652.

Robson, K., Humphrey, C., Kalifa, R., and Jones, J. 2007: Transforming auditing technologies: Business risk audit methodologies and the audit field. Accounting, Organization and Society 32: 409-432

Scott, W.R. 2008: Lords of the Dance: Professionals as Institutional Agents. Organization Studies 29, 219-238.

Smets, M., Morris, T. and Greenwood, R. 2012: From practice to field: A multilevel model of practicedriven institutional change. Academy of Management Journal 55, 877-904.

Suddaby, R., Cooper, D.J. and Greenwood, R. 2007: Transnational regulation of professional services: governance dynamics of field level organizational change. Accounting Organizations and Society $32,333-362$.

Suddaby, R. and Viale, T. 2011: Professionals and field-level change: Institutional work and the professional project. Current Sociology 59, 423-442.

Von Nordenflycht, A. 2010: What is a professional service firm? Toward a theory and taxonomy of knowledge-intensive firms. Academy of management Review 35, 155-174.

Williams, H. 2001:. Business risk. Accountancy, 127, 140. 
